\title{
Identification and substrate utilisation of fungi associated with low country live wood termite, Glyptotermes dilatatus Bugnion \& Popoff and the host plant, Camellia sinensis L.O. Kuntze
}

\author{
P.D. Senanayake ${ }^{1}$ K.M. Mohotti ${ }^{2}$ and P.A. Paranagama ${ }^{3 *}$ \\ ${ }^{\prime}$ Entomology Division, Tea Research Institute, Ratnapura. \\ ${ }^{2}$ Tea Research Institute, Talawakelle. \\ ${ }^{3}$ Department of Chemistry, Faculty of Science, University of Kelaniya, Kelaniya.
}

\begin{abstract}
The low country live wood termite (Glyptotermes dilatatus) is known to be associated with wood decaying fungi on decayed tea (Camellia sinensis var Assamica) stems. The diversity and prevalence of wood decaying fungi in decayed tea stems however have not been studied extensively. In this study, wood decaying fungi were isolated from decayed tea stems of TRI 4042 cultivar, living termites ( $G$. dilatatus) and termite galleries collected from St. Joachim Tea Estate, Ratnapura, Sri Lanka. Of the fifteen fungi isolated, thirteen were identified using molecular taxonomy. This is the first report of isolation and identification of wood decaying fungi associated with decayed tea stumps. Among the identified fungi species, seven, six, and twelve fungal strains were recovered from the living termites, termite occupied galleries and decayed tea stems, respectively. Fusarium solani, Fusarium sp.1, Fusarium sp. 2, and Rhizomucor variabilis were the common fungi isolated. Results on substrate utilisation patterns of seven fungal species revealed that all the fungi were able to produce at least two enzymes to utilise the test substrates. Further, except with $R$. variabilis and Neosartorya fischeri, these fungi could digest cellulose and pectin either by producing polygalactouronase or pectate lyase. In utilisation of lignin, none of the test fungi produced laccase although all were able to produce peroxidase.
\end{abstract}

Keywords: Camellia sinensis, Glyptotermes dilatatus, molecular identification of fungi, substrate utilisation, termites, wood decaying fungi.

\section{INTRODUCTION}

The nature of the relationship between insects and fungi is still a subject of debate although a complex relationship between insects and fungi has been studied extensively.
Fungal association of termites has been studied by several scientists (Zoberi \& Grace, 1990; Jayasimha, 2006) and it has been shown that termites prefer consuming wood decayed by certain fungi than wood that is not decayed (Esenther et al., 1961). Smythe et al. (1967) have reported that termites are attracted to decayed wood by wood decaying fungi, and many termite species also ingest excessive amounts of decayed wood than wood that is not decayed. Fungi associated with cellulolytic decay play an important role in termite nutrition and orientation to food materials (Cornelious et al., 2002), as the fungi can modify the texture of the wood to favour termite feeding and detoxify the toxic compounds present in plants (Beard, 1974; Jayasimha, 2006). Zoberi and Grace (1990) have reported the isolation of forty species of cellulolytic and pathogenic fungi associated with Reticulitermes flavifes (Koller). It has also been shown that the environment of live termites is favourable for the growth of fungi as termites change the moisture content of the wood of the host plant (Beard, 1974). Interactions between termites and fungi range from agonistic to mutualistic and many examples of symbiotic associations between fungi and termites have been reported (Jayasimha, 2006). Termite species of the sub family Macrotermitinae cultivate the fungus, Termitomyces sp. for food. The termites cannot live without this fungus and the fungus cannot survive without the termites (Henrik et al., 2005). In 2005, Wright et al. have reported that Metarhizium anisopliae isolated from dead alates of Coptotermes formosanus was detrimental to termites. It was also shown that these fungi are present in both interior and exterior surfaces of the termites. The ability of the termites to act as a vehicle 
for fungi was demonstrated by the isolation of fungi from the exterior surfaces and gut tissues of termites. The observation of hyphae, conidiophores, and conidia clinging to the bodies and appendages of termites further proved the presence of fungi in interior surfaces of termites (Jayasimha, 2006)

The low country live wood termite, Glyptotermes dilatatus is a major insect pest of low grown tea in Sri Lanka. It has been reported that the alates of $G$. dilatatus are attracted to decayed stems and first colonise inside the decayed stem, and continue their feeding to undecayed wood of the tea plant (Vitarana \& Mohotti, 2008). A tea plant infested by $G$. dilatatus predisposes the gradual deterioration and leads to bush debilitation and ultimately decease of tea bushes (Vitarana \& Mohotti, 2008). High yielding tea varieties planted in low grown areas contain soft wooded skeletons that suffer massive die back and they are highly vulnerable to wood decaying fungi (Sivapalan \& Senaratna, 1981). In the laboratory, we have been able to observe that the hexane fraction of wood rot extract obtained from decayed stem of TRI 4042 is more attractive to alates of $G$. dilatatus when compared with the hexane fraction of decayed stems obtained from tea cultivars TRI 2023, TRI 2027 and TRI 4049 (Senanayke et al., 2014). A hypothesis formulated in the current investigation was that the biodiversity observed within and among the fungi assemblages could be correlated with the attraction of $G$. dilatatus to decayed stem. Hence the present study was initiated as a survey of fungi associated with termite infested decayed stems of the tea cultivar TRI 4042, living termites and termite galleries, as fungi play a positive role in wood decay and orientation of termites (Cornelious et al., 2002). The study was further extended to utilisation of carbon sources by selected fungal species, to investigate the ability of substrate utilisation and evaluate the ability to decompose structural and storage components in vitro using pure substrates. It has been reported that enzymes, esterases, lipases, pectinases and polygalacturonases are responsible for the degradation of plant tissues (Petrini et al., 1993). In our ongoing research programme on investigation of the potential of integrated pest management method to control $G$. dilatatus, it was confirmed that the termites are attracted to decayed tea stems (Senanayake et al., 2014). Therefore, the work reported in the present study was aimed at demonstrating that the fungi living in live termites/termite galleries/decayed stumps play a major role in facilitating the decomposition of wood. To our knowledge, this is the first investigation providing data on the biodiversity and substrate utilisation of wood decaying fungi isolated from decayed tea stems.

\section{METHODOLOGY}

\section{Experimental site and sample collection}

A thirteen year old tea field was selected for this study and 2 1/2 year old pruned stems from TRI 4042 were collected. Field no. 1 of St. Joachim Tea Estate in Ratnapura, Low Country Regional Centre of the Tea Research Institute (latitude $6^{\circ} 40^{\prime} 58^{\prime} \mathrm{N}$ and longitude $80^{\circ}$ 23'57' E and elevation $128 \mathrm{~m}$ amsl), which was infested with the low country live wood termite was chosen. Three study plots consisting of 100 tea bushes per plot were demarcated.

\section{Collection of termites and tea stems}

Samples were collected from the three study plots. Six termite infested bushes were selected randomly, and six decayed stumps intact with undecayed wood containing termite colonies were collected from each plot. The samples were brought to the laboratory in sealed clean polythene bags and kept in covered plastic boxes until they were used in the experiments. The samples were processed within $48 \mathrm{hrs}$ for development of cultures. Fungi were isolated from the collected decayed tea stems of TRI 4042 cultivar, termite galleries in tea stems and living termites.

\section{Isolation of fungi from decayed stumps, termite galleries and living termites}

\section{Isolation of fungi from decayed stumps of tea plant}

The decayed stumps were cleaned using tap water to remove soil particles and kept for a few minutes to drain off excess water. The stumps were dissected into small segments (approximately $1 \times 1 \times 1 \mathrm{~cm}$ ) and composite samples were made. Twenty pieces were selected randomly and surface sterilised by sequential immersion for $10 \mathrm{~s}$ in $95 \%$ ethanol, $3 \mathrm{~min}$ in $0.5 \%$ sodium hypochlorite and $30 \mathrm{~s}$ in $75 \%$ ethanol and kept on a sterilised filter paper to drain excess moisture (Balasooriya, 1998; Guo et al., 2003). Surface sterilised segments from each stem sample were inoculated into sterilised potato dextrose agar (PDA) plates supplemented with $1 \%$ streptomycin (4 segments/ plate). The cultures were incubated at $25{ }^{\circ} \mathrm{C}$ for $7-14$ days. Developing fungal colonies from each segment were sub-cultured in $2 \%$ malt extract agar (MEA) for further investigation (Balasooriya, 1998; Kannangara et al., 2009). The fungi were photographed and deposited as voucher specimens at the Department of Chemistry, University of Kelaniya, Sri Lanka and the Tea Research Institute of 
Sri Lanka under the accession numbers PS/WR/1, PS/ $\mathrm{WR} / 2, \mathrm{PS} / \mathrm{WR} / 3, \mathrm{PS} / \mathrm{WR} / 4, \mathrm{PS} / \mathrm{WR} / 5, \mathrm{PS} / \mathrm{WR} / 6, \mathrm{PS} /$ $\mathrm{WR} / 7, \mathrm{PS} / \mathrm{WR} / 8, \mathrm{PS} / \mathrm{WR} / 9, \mathrm{PS} / \mathrm{WR} / 10, \mathrm{PS} / \mathrm{WR} / 11$, $\mathrm{PS} / \mathrm{WR} / 12$ and $\mathrm{PS} / \mathrm{WR} / 13$ (Figure 1).

\section{Isolation of fungi from termite galleries}

Six termite infested bushes from the tea cultivar, TRI 4042 were sampled and a composite sample was made using ten pieces (approximately $1 \mathrm{~cm}$ length) of termite galleries from a tea bush, accommodating a total of 60 pieces. Twenty pieces were randomly selected from the composite sample and surface sterilised using the method described by Guo et al. (2003). Surface sterilised samples were placed on PDA and incubated at $25{ }^{\circ} \mathrm{C}$ for $7-14$ days. Developing fungal colonies from each piece were sub-cultured in $2 \%$ MEA for further investigation (Balasooriya, 1998; Kannangara et al., 2009). They were photographed and deposited as voucher specimens at the Department of Chemistry, University of Kelaniya, Sri Lanka and the Tea Research institute of Sri Lanka under the accession numbers $\mathrm{PS} / \mathrm{TG} / 1, \mathrm{PS} / \mathrm{TG} / 2, \mathrm{PS} /$ TG/3, PS/TG/4, PS/TG/5 and PS/TG/6 (Figure 1).

\section{Isolation of fungi from living termites}

Samples from six termite infested bushes were collected from TRI 4042 cultivar and a composite sample of sixty living termites was obtained by collecting 10 living termites from each infested bush. Randomly selected twenty living termites from the composite sample were surface sterilised by using the $1 \%$ sodium hypochlorite and then rinsed three times with sterile distilled water (Jayasimha, 2006). These termites were inoculated on to sterilised PDA and incubated for $4-7$ days. Three replicates were prepared and the developing fungal colonies from each termite were sub-cultured into $2 \%$ MEA for further investigation (Balasooriya, 1998; Kannangara et al., 2009). They were photographed and deposited as voucher specimens at the Department of Chemistry, University of Kelaniya, Sri Lanka and the Tea Research Institute of Sri Lanka under the accession numbers $\mathrm{PS} / \mathrm{TM} / 1, \mathrm{PS} / \mathrm{TM} / 2, \mathrm{PS} / \mathrm{TM} / 3, \mathrm{PS} / \mathrm{TM} / 4, \mathrm{PS} /$ TM5, PS/TM/6 and PS/TM/7 (Figure 1).

Morphological identification of fungi isolated from living termites, termite galleries and decayed tea stems

Morphological identification of each fungus was carried out using the sticky tape method (Felgel, 1980) and identification keys (Barnett, 1960; Domsch et al., 1993). The fungal cultures were examined periodically and identified when they sporulated. The cultures were separated into groups based on their morphological characteristics including growth pattern, colony texture, pigmentation, and growth rate of the colonies on PDA. When the fungal colonies sporulated on PDA, small plaques from the edge and the centre of each growing colony were transferred onto glass slides, and examined using a compound light microscope (Leica DMLS, USA) for characteristics of their vegetative and reproductive structures such as hyphal colour and structures, shape and size of conidia, conidiophores, and microsclerotia (Kumar et al., 1998; Kannangara et al., 2009). The percentage frequency of occurrence of each fungus was calculated using the following formula;

$$
\begin{aligned}
& \% \text { Frequency } \\
& \text { of occurrence }
\end{aligned}=\frac{\begin{array}{c}
\text { No. of pieces colonised } \\
\text { by the fungus }
\end{array}}{\begin{array}{c}
\text { Total number of } \\
\text { pieces plated }
\end{array}} \times 100
$$

\section{Molecular identification of isolated fungi}

The identification of isolated pure strains of the fungi was done using a molecular biological protocol by genomic DNA extraction, amplification and sequencing.

\section{DNA extraction}

The fungal isolates were grown on PDA plates for $4-7$ days and the mycelia were harvested and ground in liquid nitrogen. Total DNA was extracted from the ground mycelium of each fungus using a DNeasy Plant Mini Kit (Qiagen, USA) according to the manufacturer's protocol.

\section{Polymerase chain reaction (PCR) amplification}

PCR was carried out using $25 \mu \mathrm{L}$ reaction volumes, each containing $2 \mu \mathrm{M}$ ITS primers (ITS1-F, ITS4-B) $(1 \mu \mathrm{L}$ each), $2 \mathrm{mM} \mathrm{MgCl} 2(2 \mu \mathrm{L}), 2 \mu \mathrm{M}$ dNTPs $(2.5 \mu \mathrm{L})$ and Taq polymerase $(0.5 \mu \mathrm{L})$, buffer $(5 \mu \mathrm{L}) \mathrm{H}_{2} \mathrm{O}(12 \mu \mathrm{L})$. Taq polymerase was added to the mixture just before the start of PCR. Initial denaturation was done at $94{ }^{\circ} \mathrm{C}$ for 4 mins, and $45 \mathrm{~s}$ for other following denaturation steps. Primer annealing was done at $55^{\circ} \mathrm{C}$ for one min and extension was done at $72{ }^{\circ} \mathrm{C}$ for $11 / 2$ mins. Seven mins were given for the final extension. The PCR was carried out for about 30 cycles to obtain maximum PCR products. Success of PCR was confirmed by running the product in agarose gel. ITS1-F (5' - CCT GGT CAT TTA GAG GAA GTA A - 3') and ITS4-B (5' - CAG GAG ACT TGT ACA CGG TCC AG - 3') primers were used for amplification (Nicolotti et al., 
2009). Amplified and purified DNA was subjected to DNA sequencing and the obtained sequences were submitted to the GenBank as a nucleotide query and compared with already existing DNA sequences using NCBI BLAST ${ }^{\circledR}$ (http://www.ncbi.nlm.nih.gov/blast/). The most similar reference sequences with the query sequences were obtained and used to identify the genus or species of the fungus. The isolates were assigned to a species if the sequence was $\geq 99 \%$ similar to a valid species sequence deposited with NCBI GenBank.

Utilisation of carbon sources by selected fungi associated with decayed tea stems, termite galleries and living termites

The ability of seven frequently isolated fungi species (F. solani, Fusarium sp. 1, Fusarium sp. 2, Aspergillus tamari, Aspergillus aculeatus, $R$. variabilis and $N$. fischeri) to produce extracellular enzymes that degrade plant cell wall components and storage materials was tested using pure substrates; starch, pectin, cellulose and lignin through extracellular enzymes. Each sample was replicated three times.

\section{Cellulose}

Cellulose agar medium was prepared with the addition of $1 \%$ cellulose powder to the basal medium at $\mathrm{pH}$ 6.2 (Eggins \& Pugh, 1961). The agar slants containing cellulose medium $(6 \mathrm{~mL})$ were autoclaved at $121{ }^{\circ} \mathrm{C}$ for 20 mins. After sterilisation the solution in each test tube was mixed thoroughly by hand shaking. Immediately, the test tubes were placed as slants and cooled in an ice bath to prevent the sedimentation of cellulose. Then the agar slants were inoculated with the test fungi and incubated at room temperature $\left(28 \pm 2{ }^{\circ} \mathrm{C}\right)$ for a month. Tubes were observed weekly. Cellulose utilisation was indicated by clearing of the cellulose agar medium beneath and around the actively growing colonies (Kannangara et al., 2009).

\section{Starch}

The ability to degrade starch by each fungus was assessed through amylolytic enzymes of the test fungi. The medium was prepared using Difco nutrient agar with $5 \%$ starch (Hankin \& Anagnostakis, 1975; Kannangara et al., 2009). The starch agar plates were inoculated separately with the test fungi and incubated at room temperature $\left(28 \pm 2{ }^{\circ} \mathrm{C}\right)$ for $3-5$ days. Test plates were flooded with $1 \% \mathrm{KI} / \mathrm{I}_{2}$ solution and the production of a clear zone around the active fungal colony indicated the amylolytic activity.

\section{Pectin}

The ability of the test fungal species to utilise pectin was assessed by the pectolytic activity of the two enzymes polygalacturonase and pectate lyase. Plates were prepared using the basal medium amended with $0.5 \%$ of liquid citrus pectin (Sigma Aldrich Canada Ltd.) (Eggins \& Pugh, 1961; Kannangara et al., 2009). The medium at $\mathrm{pH} 5$ was used to detect polygalacturonase activity and at $\mathrm{pH} 7$ it was used to detect pectate lyase activity for optimal activity of enzymes. After incubation of fungal colonies, the plates were flooded with a $1 \%$ aqueous solution of cetavlon (cetyle trimethyl ammonium bromide), which precipitated intact pectin in the medium. Thus a clear zone around the active colonies indicates polygalactouranase activity and the pectate lyase activity of each fungus tested (Hankin \& Anagnostakis, 1975; Abdel-Raheem \& Shearer, 2002; Kannangara et al., 2009).

\section{Lignin}

Lignin degradation was assessed indirectly by the production of three enzymes, laccase, peroxidase and tyrosinase, which are involved in depolymerisation of lignin. Each fungal strain was grown on MEA at $\mathrm{pH}$ 7. After incubation of fungal colonies at $22{ }^{\circ} \mathrm{C}$ for $4-5$ days, the production of each of the three enzymes was observed using the drop tests (Stalpers, 1978; Kannangara et al., 2009). The production of laccase was observed using a solution of naphthol $(0.1 \mathrm{M})$ in $96 \%$ ethanol. Drops from this solution were tested on the active marginal hypae of each of the fungal species using a dropper. Diffusion of purplish colouration into the medium indicated the presence of laccase (Stalpers, 1978; Kananagra et al., 2009). The production of peroxidase was observed using a solution of $0.4 \%$ $\mathrm{H}_{2} \mathrm{O}_{2}$ and $1 \%$ pyrogallol in water $\left[25 \mathrm{~mL} \mathrm{H}_{2} \mathrm{O}_{2}(0.4 \%)\right.$ : $25 \mathrm{~mL}$ pyrogallol (1\%)]. Drops from this solution (freshly prepared) were tested on the hypae of each of the test fungi. Yellow brownish colouration indicated the production of peroxidase (Amirita et al., 2012). The production of tyrosinase was tested using a test solution of $p$-cresol $(0.1 \mathrm{M})$ prepared in $96 \%$ ethanol. Drops from this solution were tested on the marginal hypae of each test fungal species. Appearance of an orange brown colour diffusing into the medium indicates production of tyrosinase (Kaarik, 1965; Amirita et al., 2012).

\section{Data analysis}

Analysis of variance was carried out for comparison of frequency of occurrence of isolated fungi from the decayed wood, termite galleries and living termites using SAS. 
Percentages were transformed to arcsine values prior to analysis. Mean separation was carried out using Tukey's studentised test (Aukema et al., 2005).

\section{RESULTS AND DISCUSSION}

\section{Isolation of fungi from decayed stumps, termite galleries and living termites}

Senanayake et al. (2014) have confirmed that $G$. dilatatus is attracted to decayed tea stems. In this study molecular taxonomy of wood decaying fungi was done in order to identify the fungal species present in decayed stumps, living termites and termite galleries. The total number of fungal species isolated from the three locations was fourteen. Using DNA sequencing studies the identity of twelve of them was confirmed (Figure 1). The number of fungi identified from decayed stumps, which were two and half years old (decayed) pruned stems, termite galleries and living termites were 13,6 and 7, respectively.

The frequencies of occurrence of $F$. solani, Fusarium sp. 1, Fusarium sp. 2, T. corrugata and Lasiodiplodia sp. in living termites, termite galleries and decayed stumps of TRI 4042 were between $25-60 \%$ and it was less than $25 \%$ in $R$. variabilis, A. tamari, A. aculeatus, Trichoderma harzianum, B. ochroleuca, P. lilacinum and $F$. oxysporum (Table 1).

In living termites, $25-60 \%$ colonisation frequencies were observed for $F$. solani, Fusarium sp. 1 and Fusarium sp. 2, while A. tamari, A. aculeatus, $N$. fischeri and $R$. variabilis showed the frequencies in the range of $10-15 \%$. It was noted that $N$. fischerri was only present in living termites while both Lasiodiplodia sp. and $B$. ochroleuca were not observed in living termites. However, Lasiodiplodia sp. $(40-42 \%)$ and B. ochroleuca $(5-7 \%)$ assemblages were detected in termite galleries and decayed tea stumps, and A. tamari, A. aculeatus, N. fischerri, T. harzianum, P. lilacinum were absent in termite galleries.

Table 2 presents the frequencies of occurrence of wood decaying fungi species common in decayed stumps, living termites and termite galleries. The results revealed that the frequencies of four fungal species, F. solani, Fusarium sp.1, Fusarium sp. 2 and R. variabilis are significantly different $(\mathrm{F}=48.91, \mathrm{df}=3, \mathrm{p}<0.0015)$ among decayed stumps, living termites and termite galleries. Mean separation indicated that the frequency of occurrence $(50 \pm 1.12)$ of $F$. solani in decayed stumps was significantly $(\mathrm{p}<0.05)$ higher than those of living termites $(25 \pm 1.12)$ and termite galleries $(30 \pm 2.24)$, while the frequency of occurrence was not significantly different $(\mathrm{p}>0.05)$ between living termites and termite galleries. The frequency of occurrence $(36.67 \pm 2.9)$ of Fusarium sp.1 in decayed stumps was significantly lower $(\mathrm{p}<0.05)$ than that of living termites $(60 \pm 1.94)$, and termite galleries $(55 \pm 1.94)$, while it was not significantly different $(\mathrm{p}>0.05)$ between living termites and termite galleries. Frequencies of occurrence of Fusarium sp. 2 were not significantly different $(\mathrm{p}<0.05)$ among decayed stumps, termite galleries and living termites. The frequencies of occurrence of $R$. variabilis among decayed stumps, termite galleries and living termites were also not significantly different $(\mathrm{p}>0.05)$.

It has been reported that Fusarium sp. and Aspergillus sp. belonging to the family deuteromycetes cause soft rot of wood in trees, while $T$. corrugata belonging to the family basediomycetes cause wood decay (Eaton \& Hale, 1993). Further it has also been reported that Lasiodiplodia sp. are associated in tea stems and cause stem canker (Pradeepa et al., 2014). In the present study, these fungi were also isolated from decayed stumps, termite galleries and living termites indicating that they facilitate wood decaying in the tea stem. Schubert et al. (2008) have reported that T. harzianum is a parasitic fungus on other fungi and it is used as an effective bio-control agent to control other fungi. Therefore $T$. harzianum could be a parasitic fungus on wood decaying fungi associated in decayed tea stumps. Rizomucor variabilis is common in wood at ground contact and it is less important for wood deterioration (Eaton \& Hale, 1993). Therefore Fusarium spp., Aspergillus spp., T. corrugata and Lasiodiplodia spp. are the potential fungi that cause soft rot in wood of plants.

Utilisation of carbon sources by selected wood decaying fungi associated with decayed tea stems, termite galleries and living termites

Colonisation of the host tissues by wood decaying fungi involves the digestion of constituents of plant cell wall, and that can be achieved by enzymatic digestion of epidermal cell layers. Lignin, cellulose and pectin are the main components of the cell wall and it is reported that phytopathogens can produce different types of enzymes to digest the components of the cell walls. The present study was conducted with fungi isolated from two and a half years old decayed stems of the cultivar TRI 4042, living termites ( $G$. dilatatus) and termite galleries. The ability of the selected fungi to produce extracellular enzymes that degrade plant cell wall components and storage materials was investigated. The results revealed that all the test fungi; F. solani, Fusarium sp. 1, Fusarium sp. 2, A. tamari, A. aculeatus, $R$. variabilis and $N$. fischerii 


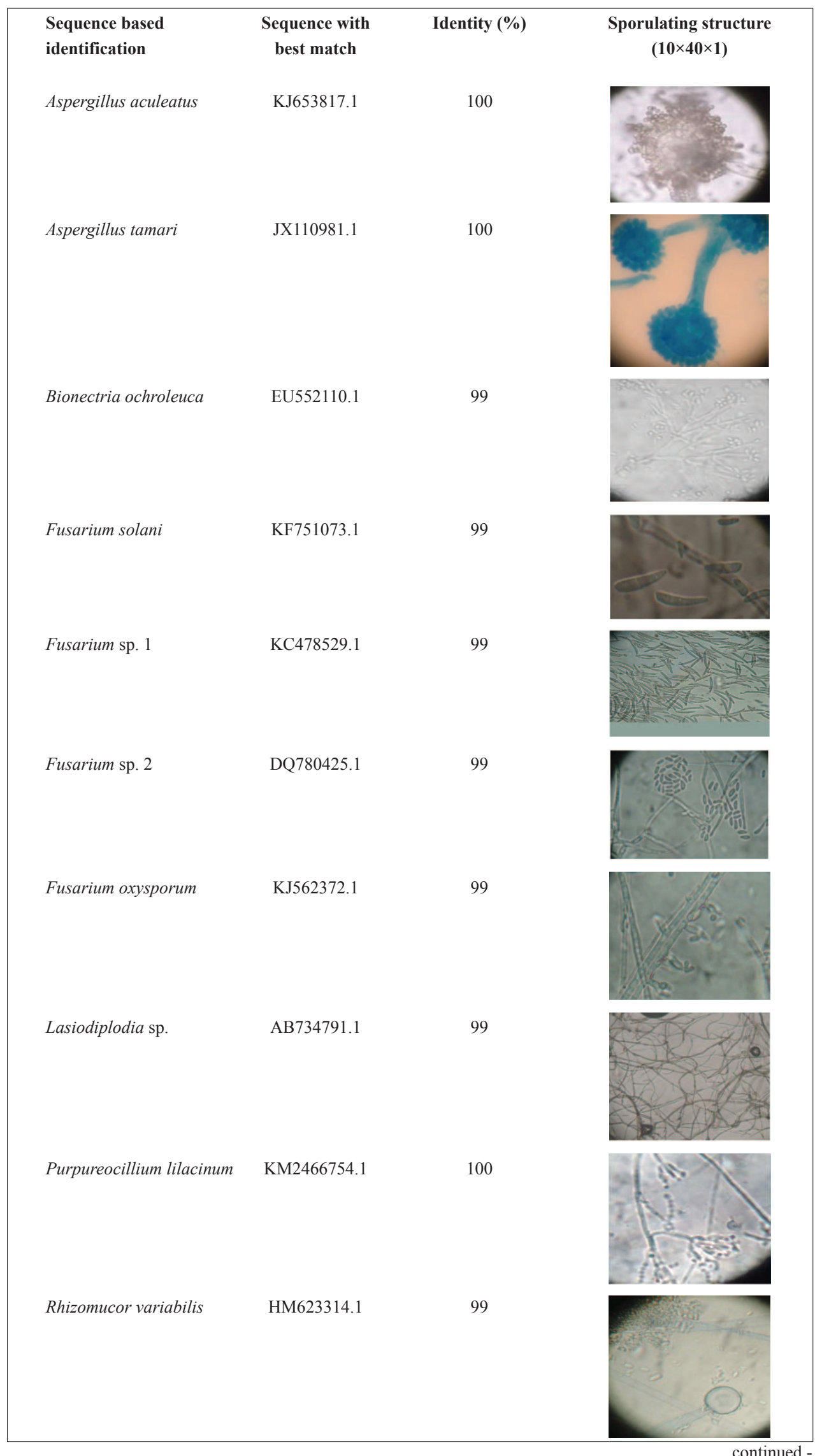


continued from page 180

\begin{tabular}{|lccc|}
\hline $\begin{array}{l}\text { Sequence based } \\
\text { identification }\end{array}$ & $\begin{array}{c}\text { Sequence with } \\
\text { best match }\end{array}$ & Identity (\%) & $\begin{array}{c}\text { Sporulating structure } \\
(\mathbf{1 0 \times 4 0 \times 1 )}\end{array}$ \\
Trametes corrugate & EU661875.1 & 99 & \\
Trichoderma harzianum & KM207772.1 & 100 & \\
Unidentified sp. & & \\
\hline
\end{tabular}

Figure 1: Fungal species isolated from decayed stumps, termite occupied galleries and living termites occupied in stems of cultivar TRI 4042

Table 1: Frequency of occurrence of different fungal species isolated from surface sterilised living termites, termite galleries and decayed stumps of TRI 4042

\begin{tabular}{lccc}
\hline \multirow{2}{*}{ Fungal species } & \multicolumn{3}{c}{ Frequency of occurrence (\%) } \\
\cline { 2 - 4 } & Living termites & Termite galleries & Decayed tea stumps \\
\hline A. aculeatus & $10 \pm 2.24$ & ND & $3.33 \pm 0.65$ \\
A. tamari & $10 \pm 1.94$ & ND & $1.67 \pm 0.65$ \\
B. ochroleuca & ND & $5 \pm 1.12$ & $6.67 \pm 2.58$ \\
F. oxysporum & ND & ND & $3.33 \pm 0.65$ \\
F. solani & $25 \pm 1.12$ & $30 \pm 2.24$ & $50 \pm 1.12$ \\
Fusarium sp. 1 & $60 \pm 1.94$ & $55 \pm 1.94$ & $36.7 \pm 2.9$ \\
Fusarium sp. 2 & $30 \pm 1.12$ & $25 \pm 1.12$ & $30 \pm 2.24$ \\
Lasiodiplodia sp. & ND & $40 \pm 2.96$ & $41.67 \pm 2.33$ \\
N. fischeri & $15 \pm 1.12$ & ND & ND \\
P. lilacinum & ND & ND & $5 \pm 0$ \\
R. variabilis & $10 \pm 1.94$ & $10 \pm 1.12$ & $16.67 \pm 0.65$ \\
T. corrugata & ND & ND & $33.3 \pm 1.29$ \\
T. harzianum & ND & ND & $11.67 \pm 2.81$ \\
\hline
\end{tabular}

$\mathrm{ND}=$ not detected 
Table 2: Mean percentage frequencies of occurrence of fungal species common to decayed tea stumps, termite galleries and living termites

\begin{tabular}{lcccr}
\hline & \multicolumn{4}{c}{ \% Frequency of occurrence \pm SE } \\
\cline { 2 - 5 } & F. solani & Fusarium sp. 1 & Fusarium sp. 2 & R. variabilis \\
\hline Living termites & $25 \pm 1.12^{\mathrm{b}}$ & $60 \pm 1.94^{\mathrm{a}}$ & $30 \pm 1.12^{\mathrm{a}}$ & $10 \pm 1.94^{\mathrm{a}}$ \\
Termite galleries & $30 \pm 2.24^{\mathrm{b}}$ & $55 \pm 1.94^{\mathrm{a}}$ & $25 \pm 1.12^{\mathrm{a}}$ & $10 \pm 1.12^{\mathrm{a}}$ \\
Decayed tea stumps & $50 \pm 1.12^{\mathrm{a}}$ & $36.67 \pm 2.9^{\mathrm{b}}$ & $30 \pm 2.24^{\mathrm{a}}$ & $10.67 \pm 1.29^{\mathrm{a}}$ \\
\hline
\end{tabular}

Each data point represents the mean of three replicates \pm SE; means followed by the same letter(s) in each column are not significantly different according to the Tukey's studentised range test and $\operatorname{ANOVA}(\mathrm{p} \leq 0.05)$.

were able to utilise starch (Table 3). Cellulose utilisation ability was exhibited by Fusarium sp. 1, F. solani and $A$. tamari. It has been reported that $F$. solani and Fusarium sp. isolated from leaf litter in a forest were able to produce cellulase (Agustini et al., 2012), and these findings are in agreement with the present study.

The production of both pectin and polygalacturonic acid degrading enzymes, pectate lyase and polygalctouranase, which are assumed to be responsible for the degradation of cell wall and middle lamella during penetration and colonisation of the host tissue by fungi, was evaluated. The results revealed that five test fungi species, Fusarium sp. 1, F. solani, A. tamari, Fusarium sp. 2 and A. aculeatus utilised pectin by producing pectate lyase, whereas $R$. variabilis and $N$. fischeri did not produce pectate lyase.
Production of polygalctouranase was observed in Fusarium sp. 1, F. solani, A. tamari and Fusarium sp. 2, while $R$. variabilis, $A$. aculeatus and $N$. fischeri were not able to produce polygalctouranase. The third major component of wood cell wall is lignin. The ability to utilise lignin (lignin degradation) was evaluated by using the production of three enzymes; laccase, peroxidase and tyrosinase. Lignin degradation by white rot fungi (basidiomycetes) has been studied extensively (Eaton \& Hale, 1993). The results revealed that all test fungi can utilise lignin by producing peroxidase but only three fungi, Fusarium sp. 2, Fusarium solani and A. aculeatus could produce tyrosinase to support the digestion of lignin, while none of the test fungi could produce laccase (Table 3). Rhizomucor variabilis and $N$. fischeri have less contribution for the deterioration of wood because it did not produce cellulose, pectate lyase and polygalctouranase.

Table 3: Substrate utilisation patterns of fungi isolated from surface sterilised G. dilatatus

\begin{tabular}{|c|c|c|c|c|c|c|c|}
\hline \multirow[b]{2}{*}{ Fungal species } & \multirow[b]{2}{*}{ Cellulose } & \multirow[b]{2}{*}{ Starch } & \multicolumn{2}{|c|}{ Pectin } & \multicolumn{3}{|c|}{ Lignin } \\
\hline & & & Polygalactouronase & Pectate lyase & $\mathrm{P}$ & $\mathrm{L}$ & $\mathrm{T}$ \\
\hline R. variabilis & - & + & - & - & + & - & - \\
\hline Fusarium sp. 1 & + & + & + & + & + & - & - \\
\hline Fusarium sp. 2 & + & + & + & + & + & - & + \\
\hline A. tamari & + & + & + & + & + & - & - \\
\hline F. solani & + & + & + & + & + & - & + \\
\hline A. aculeatus & + & + & - & + & + & - & + \\
\hline N. fischeri & - & + & - & - & + & - & - \\
\hline
\end{tabular}

Number of replicates $=3 \quad \mathrm{~L}=$ Laccase $\quad \mathrm{P}=$ Peroxidase $\quad \mathrm{T}=$ Tyrosinase

\section{CONCLUSION}

Decayed tea stumps of TRI 4042 cultivar occupied by $G$. dilatatus contained fourteen species of fungi and twelve species were identified as F. solani, Fusarium sp. 1, Fusarium sp. 2, T. corrugata, Lasiodiplodia sp., $R$. variabilis, A. tamari, A. aculeatus, T. harzianum,
B. ochroleuca, P. lilacinum and F. oxysporum. Six pure cultures were isolated from the termite galleries and identified as F. solani, Fusarium sp. 1, Fusarium sp. 2, Lasiodiplodia sp., $R$. variabilis and B. ochroleuca. Seven pure cultures of fungi isolated from surface sterilised living termites were identified as $F$. solani, Fusarium sp. 1, Fusarium sp. 2, A. tamari, A. aculeatus, $N$. fischeri and $R$. variabilis. 
The results showed that $F$. solani, Fusarium sp. 1, Fusarium sp. 2, A. tamari and A. aculeatus could utilise cellulose when they grow in cellulose containing medium. Starch utilisation of wood decaying fungi indicated that all the test fungal species have the ability to digest starch when they grow in starchy medium. F. solani, Fusarium sp. 1, Fusarium sp. 2 and A. tamari could produce both polygalactouronase and pectate lyase to utilise pectin. The results also revealed that $A$. aculeatus produced only pectate lyase. Rhizomucor variabilis and $N$. fischeri did not produce these two enzymes. Tests carried out for lignin degradation revealed that none of the test fungi produce laccase, while all the fungi were able to produce peroxidase. Fusarium solani, A. aculeatus and Fusarium sp. 2 were able to produce tyrosinase enzyme and the other four species of test fungi were negative for tyrosinase production.

Observations of the substrate utilisation tests on pure substrates indicated that the test fungi could degrade structural components, cellulose, lignin and pectin, and the storage component starch in stems of the tea plant. Therefore, it will be useful if cultivar screening programme is evaluated for termite resistance as well as resistance to wood rot.

\section{REFERENCES}

1. Abdel-Raheem A. \& Shearer C.A. (2002). Extra cellular enzyme production by freshwater ascomycetes. Fungal Diversity 11: 1 - 19.

2. Agustini L., Efiyanti L., Faulina S.A. \& Santoso E. (2012). Isolation and characterization of cellulase- and xylanaseproducing microbes isolated from tropical forests in Java and Sumatra. International Journal of Environment and Bioenergy 3(3): $154-167$.

3. Amirita A., Sindhu P., Swetha J., Vasanthi N.S. \& Kannan K.P. (2012). Enumeration of endophytic fungi from medicinal plants and screening of extracellular enzymes. World Journal of Science and Technology 2(2): 13 - 19.

4. Aukema B.H., Werner R.A., Haberkem K.E., Illman B.H., Clayton M.K. \& Raffa K.F. (2005). Quantifying sources of variation in the frequency of fungi associated with spruce beetles: implications for hypothesis testing and sampling methodology in bark beetle symbiont relationships. Forest Ecology and Management 217: 187 - 202.

DOI: http://dx.doi.org/10.1016/j.foreco.2005.05.062

5. Balasooriya A. (1998). Study of wood rot in tea (Camellia sinensis) with special reference to that caused by Nemania diffusa (syn. Hypoxylon vesticum). PhD thesis, University of Peradeniya, Peradeniya, Sri Lanka.

6. Barnett H.L. (1960). Illustrated Genera of Imperfect Fungi, $2^{\text {nd }}$ edition, pp. 225. Burgess Publishing Company, Minnesota, USA.
7. Beard R.L. (1974). Termite biology and bait-block method of control. Connecticut Agricultural Experiment Station Bulletin 748. Connecticut Agricultural Experiment Station, New Haven, Connecticut, USA.

8. Cornelious M.L., Daigle D.J., Connick W.J., Parker A. \& Wunch K. (2002). Responses of Coptotermes formosanus and Reticulitermes flavipes (Isoptera: Rhinotermitidae) to three types of wood rot fungi cultured on different substrates. Journal of Economic Entomology 95(1): 121 - 128. DOI: http://dx.doi.org/10.1603/0022-0493-95.1.121

9. Domsch K.H., Gams W. \& Anderson T.L. (1993). Compendium of Soil Fungi, volume 1 and 2, pp. 859. Academic Press, New York, USA.

10. Eaton R.A. \& Hale M.D.C. (1993). The formation of wood. Wood, Decay, Pests and Protection, pp. 1 - 35. Chapman and Hall, London, UK.

11. Eggins H.O.W. \& Pugh G.H.F. (1961). Isolation of cellulose decomposing fungi from soil. Nature 193: 94 - 95.

DOI: http://dx.doi.org/10.1038/193094a0

12. Esenther G.R., Allen T.C., Cassida J.E. \& Shenefelt R.D. (1961). Termite attractant from fungus-infected wood. Science 134: 50.

DOI: http://dx.doi.org/10.1126/science.134.3471.50

13. Felgel T.W. (1980). Semi permanent microscope slides of micro fungi using sticky tape technique. Canadian Journal of Microbiology 26: 551 - 553.

DOI: http://dx.doi.org/10.1139/m80-095

14. Guo L.D., Huang G.R., Wang Y., He W.H., Zeng W.H. \& Hyde K.D. (2003). Molecular identification of which morphotype strains of endophytic fungi from Pinus tubulaeformis. Mycological Research 107: 680 - 685. DOI: http://dx.doi.org/10.1017/S0953756203007834

15. Hankin L. \& Anagnostakis L. (1975). The use of solid media for detection of enzyme production by fungi. Mycologia 67: $597-607$.

DOI: http://dx.doi.org/10.2307/3758395

16. Hendee E.C. (1933). The association of the termites, Kalotermes minor, Reticulitermes hesperus and Zootermopsis angusticollis with fungi. University of California Publications in Zoology, volume 39, no. 5, pp. 111 - 134. University of California Press, California, USA.

17. Henrik H.D.F.,Anders A.\& Duur K.A. (2005). Termitomyces sp. associated with the termite Macrotermes natalensis has a heterothallic mating system and multinucleate cells. Mycological Research 109(3): $314-318$.

DOI: http://dx.doi.org/10.1017/S0953756204001844

18. Jayasimha P. (2006). Interactions between Formosan subterranean termites, brown rot fungus (Gloeophyllum trabeum) and some of the fungi present in the termite integument and gut. MSc thesis, Louisiana State University, USA.

19. Kaarik A. (1965). The identification of the mycelia of wood decay fungi by their oxidation reactions with phenolic compounds. Studia Forestalia Suecia 30: $5-61$.

20. Kannangara B.T.S.D.P., Rajapaksha R.S.C.G \& Paranagama P.A. (2009). Nature and bioactivities of endolichenic fungi 
in Pseudocyphellaria sp., Parmotrema sp. and Usnea sp. at Hakgala montane forest in Sri Lanka. Letters in Applied Microbiology 48(2): 203 - 209.

DOI: http://dx.doi.org/10.1111/j.1472-765X.2008.02512.x

21. Kumar N.S., Hewavitaranage P. \& Adikaram N.K.B. (1998). Histology and fungal flora of shot-hole borer beetle (Xyleborus fornicatus) galleries in tea (Camellia sinensis). Journal of the National Science Council of Sri Lanka 26(3): $195-207$.

22. Nicolotti G., Gonthier P., Guglelmo F. \& Garbelotto M.M. (2009). A biomolecular method for the detection of wood decay fungi: focus on tree stability assessment. Arboriculture and Urban Forestry 35(1): $14-19$.

23. Petrini O., Sieber T.N., Toti L. \& Viret O. (1993). Ecology, metabolite production, and substrate utilization in endophytic fungi. Natural Toxins 1(3): 185 - 196. DOI: http://dx.doi.org/10.1002/nt.2620010306

24. Pradeepa N.H.L., Weerasena O.V.D.S.J., Liyanarachchi C.J., Karunajeewa D.G.N.P., Mahindapala K.G.J.P., Mahinda T.G.N., Rathnayake S.P., Wijesundara R.L.P. \& Abeysinghe I.S.B. (2014). Morphological and molecular characterization of fungi causing canker of tea Camellia sinensis (L.) O. Kuntze in Sri Lanka. In: Green Plantation Economy. Proceedings of the Fifth Symposium on Plantation Crop Research, BMICH, Colombo, Sri Lanka, 15 - 17 October, pp. 167 - 176.

25. Schubert M., Fink S. \& Schwarze F.W.M.R. (2008). Evaluation of Trichoderma spp. as a biocontrol agent against wood decay fungi in urban trees. Biological Control 45: $111-123$.

DOI: http://dx.doi.org/10.1016/j.biocontrol.2008.01.001

26. Senanayake P.D., Vitana B.S.V., Mohotti K.M. \& Paranagama P.A. (2014). Evaluation of the response of low country live wood termite, Glyptotermes dilatatus Bugnion \& Popoff (Isoptera: Kalotermitidae) for semiochemicals present in rotted and healthy stems of tea cultivars. In: Green Plantation Economy. Proceedings of the Fifth Symposium on Plantation Crop Research, BMICH, Colombo, Sri Lanka, 15 - 17 October, pp. $123-133$.

27. Sivapalan P. \& Senaratna K.A.D.W. (1981). Some aspects of the biology of the tea termite Glyptotermes dilatatus. Tea Quarterly 50(3): $117-122$.

28. Smythe R.V., Coppel H.C. \& Allen T.C. (1967). The response of Reticulitermes spp. and Zootermopsis angusticollis (Isoptera) to extracts from woods decayed by various fungi. Annals of the Entomological Society of America 60(1): 8 - 9 .

DOI: http://dx.doi.org/10.1093/aesa/60.1.8

29. Stalpers J.A. (1978). Identification of Wood Inhabiting Aphyllopholares in Pure Culture, pp. 10 - 11. Institute of Royal Netherlands Academy of Arts and Science, Amsterdam, The Netherlands.

30. Vitarana S.I. \& Mohotti K.M. (2008). Management of tea termites. Handbook on Tea (ed. A.K.N. Zoysa), pp. 231 - 240. Tea Research Institute of Sri Lanka, Talawakelle.

31. Wright M.S., Raina A.K. \& Lax A.R. (2005). Metarhizium anisopliae for controlling subterranean termites. Journal of Economic Entomology 98(5): 1451 - 1458.

DOI: http://dx.doi.org/10.1603/0022-0493-98.5.1451

32. Zoberi M.H. \& Grace J.K. (1990). Fungi associated with the subterranean termite Reticulitermes flavipes in Ontario. Mycologia 82(3): 289 - 294.

DOI: http://dx.doi.org/10.2307/3759899 